\title{
SEMINÁRIO CULTURA,
}

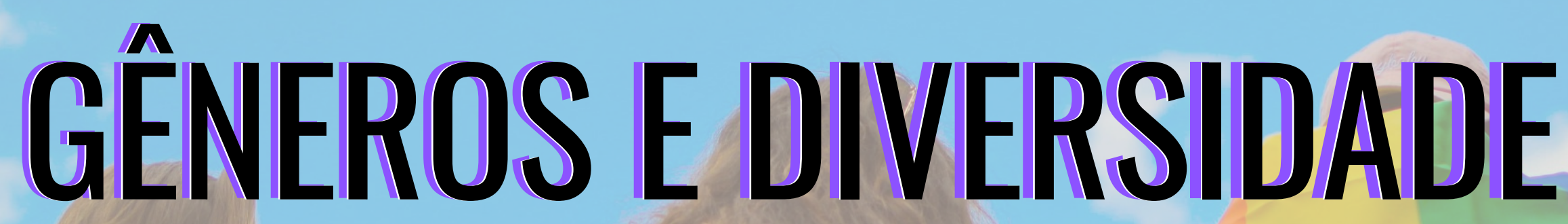

Dia 20 de maio de 2019 - Interartes - UFF

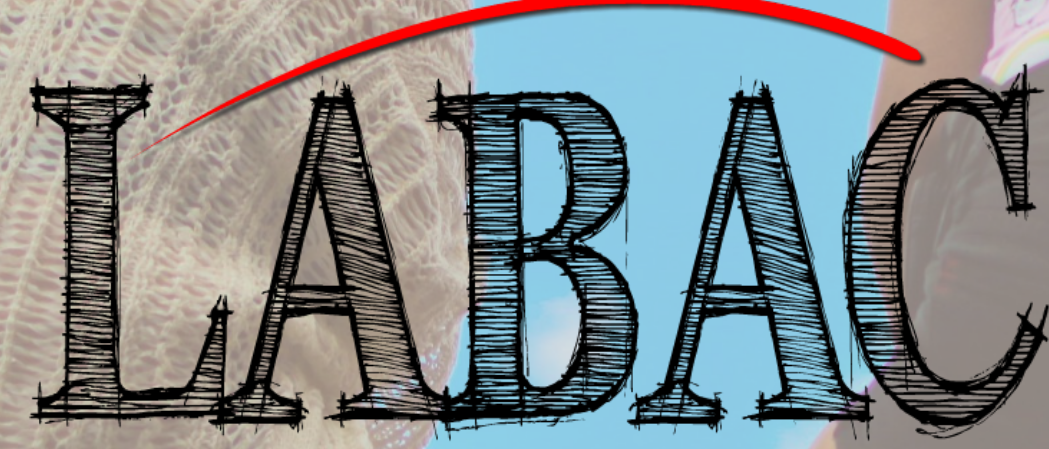

Laboratório de Ações Culturais 耳ACS = UTH"
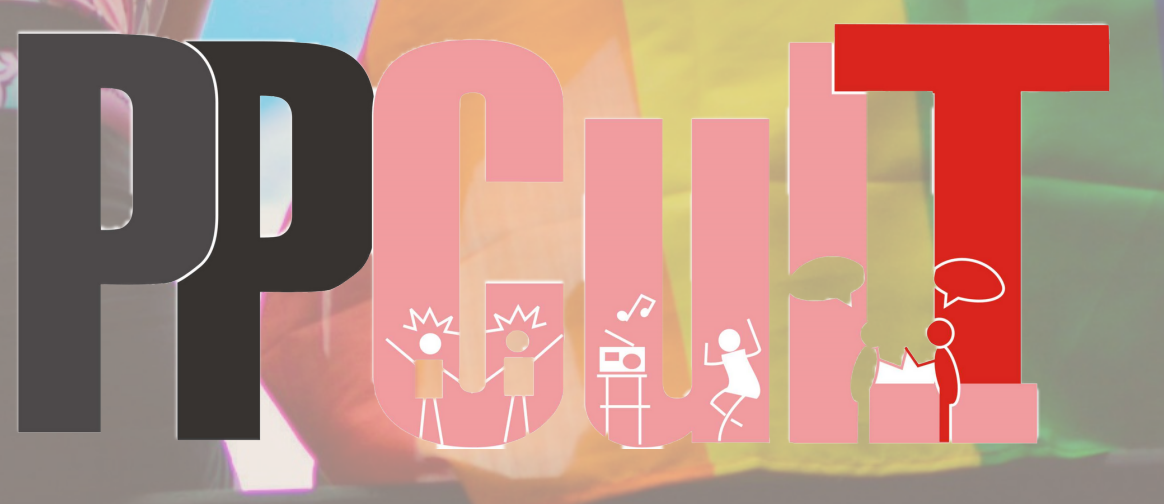

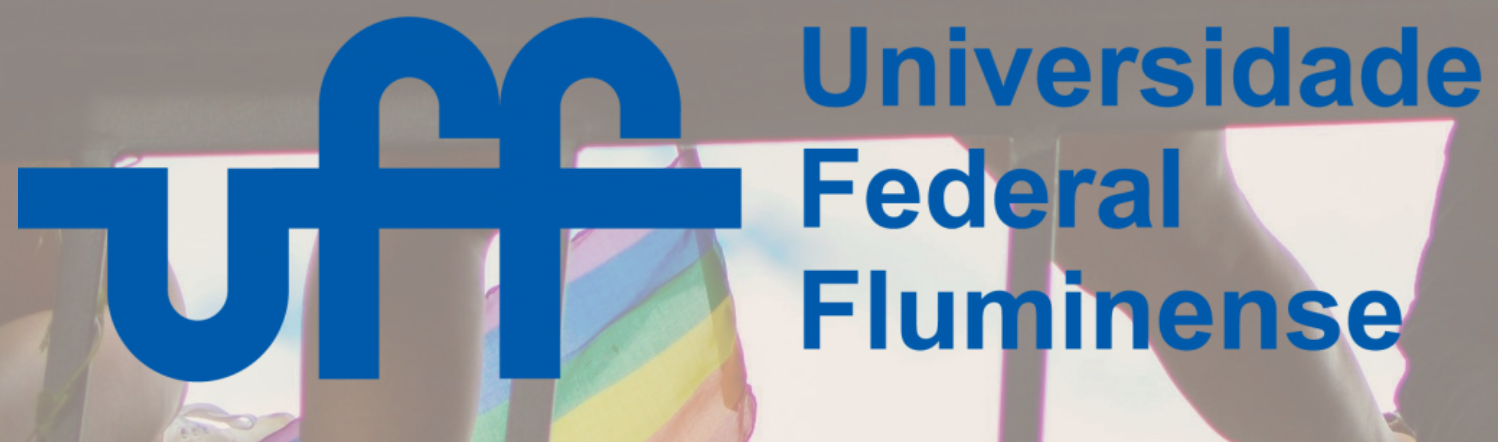

